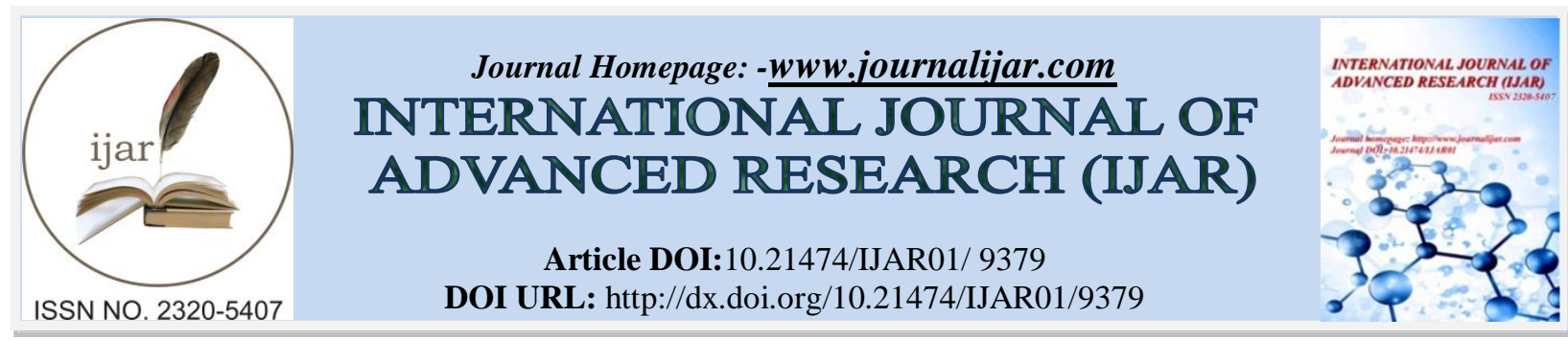

RESEARCH ARTICLE

\title{
VARIATION IN SOIL MACROFAUNA DIVERSITY IN THE DIFFERENT LAND USE TYPES IN NAMANYONYI SUB COUNTY, MBALE DISTRICT UGANDA.
}

Faruk Usman Maiyaki ${ }^{1}$, Sarah Nachuha ${ }^{1}$ and Aliyu Abubakar Shehu ${ }^{2}$.

1. Islamic university in Uganda, department of environmental sciences, Mbale, 00256, Uganda.

2. Save the Nature Foundation, Nigeria.

\section{Manuscript Info}

Manuscript History

Received: 10 May 2019

Final Accepted: 12 June 2019

Published: July 2019

\begin{abstract}
This study was conducted in Namanyonyi Sub-county, Mbale district, Uganda. It compared: soil macrofauna abundance and diversity, the physicochemical properties of the soil, and earthworms and termites variability and biomass vis-à-vis the land use types (fallow, mixed cropping and eucalyptus plantation). Each land-use type was sampled for soil macrofauna using three methods (monolith, termites transect and pitfall traps). Thirteen species of invertebrates spread across 12 orders were recorded across the different land use types. The major macrofauna groups recorded included: Hymenoptera, Blattodea, Araneae, Orthoptera, Chilopoda, coleopteran, Diplopoda, Hemiptera, Dermaptera and pseudo-Scorpionida. Generally, Hymenoptera was the most abundant of the macrofauna groups constituting about (64.77\%) of the total followed by Blattodea $(22.69 \%)$. The other macrofauna (Araneae, Diplopoda, Chilopoda, Orthoptera, Blattidae, Hemiptera, Dermaptera, Mantodea and psudoscorpionida each constituted $<10 \%$ of the total macrofauna recorded. Soil macro fauna was more diverse in eucalyptus land use types, followed by fallow and lastly mixed cropping. However, the reverse was also true for biomass. Soil chemical characteristics did not significantly vary across land use types (ANOVA, P>0.05). Pearson correlation showed that there is a moderate positive relationship between macro fauna biomass and calcium $(\mathrm{r}=$ 0.666. $\mathrm{P}<0.05$ ), The findings of this study seem to indicate that based on biomass, fallow is a better way of conserving invertebrate macrofauna while eucalyptus is the least and calcium levels in the soil determine the presence of these organisms.
\end{abstract}

Copy Right, IJAR, 2019,. All rights reserved.

\section{Introduction:-}

Land use is the use of land by humans for service and productive purposes. Land use can put much pressure on the abundance, biomass, diversity and community composition of soil macro-fauna [1]. When macro-fauna communities of important functional groups are affected by land use, essential ecosystem functions may also be affected [2].

\section{Corresponding Author:-Faruk Usman Maiyaki}

Address:-Islamic university in Uganda, department of environmental sciences, Mbale, 00256, Uganda. 
The essence of macro fauna to the diversity of tropical soil fertility has been emphasized in recent reviews [3]. The distribution, conservation and stabilization of organic matter, the precursor of soil structure (macro aggregates), soil humification, the release of immobilized soil nutrients, have all been witnessed in soils modified by termites and earthworms [3].

When vegetation and arable lands are cleared for farming, compositions and structures of soil macro fauna are often disrupted. This practice inadvertently leads to the depletion in the quantity and quality of organic matter, causing significant harm to soil living organisms. Earthworms and litter communities may often disappear and are consequently not replaced [4].

In Uganda, little studies on soil macro fauna have been carried out [5]. Some of the well-researched macro fauna groups include termites, with most of the work concentrated in natural habitats. Few quantitative studies have studied changes in diversity and abundance of subterranean species and their response to land- use intensification. Research done by [6] in Mabira forest, Uganda showed the response and importance of termites to land use change in a tropical forest and surrounding agro-ecosystems, but it was not clear how land-use practices impacted on the distribution of soil macro fauna and their effect on soil quality. Therefore, the main aim of this study was to investigate the variations in soil macro fauna diversity in the different land use types in Namanyonyi Sub County. The findings of this study will enlighten farmers in the study site about the importance of soil macro fauna and how various land use practices may affect soil living organisms.

\section{Results:-}

\section{Species richness}

A total of 13 species spread across 12 orders were recorded by this study. The major groups of soil macro fauna recorded across the different land use types at Namanyonyi Sub County included: Hymenoptera, Isoptera, Coleoptera, Chilopoda, Blattidae, Orthoptera, Dermiptera, Mantodea, Dioplopoda, Aranea, Pseudo Scorpionida, and Hemiptera.

Table 1:-showing the number of species and orders of the soil macro fauna recorded in all the land use types.

\begin{tabular}{|l|l|l|l|}
\hline Species Name & Order & Abundance & \% Proportion \\
\hline Ants & Hymenoptera & 899 & 64.77 \\
\hline Beetles & Coleoptera & 33 & 2.38 \\
\hline Centipedes & Chilopoda & 3 & 0.22 \\
\hline Cockroaches & Blattidae & 5 & 0.36 \\
\hline Crickets & Orthoptera & 38 & 2.74 \\
\hline Earwigs & Dermaptera & 5 & 0.36 \\
\hline Grasshoppers & Orthoptera & 10 & 0.72 \\
\hline Mantids & Mantodea & 2 & 0.14 \\
\hline Millepeds & Diplopoda & 2 & 0.14 \\
\hline Pseudoscorpions & Pseudoscorpionida & 1 & 0.07 \\
\hline Spiders & Araneae & 71 & 5.12 \\
\hline Termites & Isoptera & 315 & 22.69 \\
\hline White flies & Hemiptera & 4 & 0.29 \\
\hline Total & & $\mathbf{1 3 8 8}$ & $\mathbf{1 0 0}$ \\
\hline
\end{tabular}

Table 2:-Showing The Mean \pm Se Of Invertebrate Species Per Land-Use Type

\begin{tabular}{|l|l|l|l|}
\hline \multirow{2}{*}{ Species Name } & \multicolumn{3}{|l|}{ Land Use Types } \\
\cline { 2 - 4 } & Eucalyptus & Fallow & Mixed cropping \\
\hline Ants & $43.67 \pm 12.68$ & $150 \pm 40.19$ & $105.67 \pm 55.38$ \\
\hline Beetles & $2.33 \pm 0.33$ & $6.00 \pm 3.512$ & $4.00 \pm 2.00$ \\
\hline Centipedes & 0 & $2.00 \pm 0.00$ & $1.00 \pm 0.00$ \\
\hline Cockroaches & $2.00 \pm 0.00$ & $3.00 \pm 0.00$ & 0 \\
\hline Crickets & $2.50 \pm 0.50$ & $7.67 \pm 2.33$ & $3.33 \pm 0.33$ \\
\hline Earwigs & 0 & $3.00 \pm 0.00$ & 0 \\
\hline Grasshoppers & 0 & $3.00 \pm 0.00$ & $5.00 \pm 0.00$ \\
\hline
\end{tabular}




\begin{tabular}{|l|l|l|l|}
\hline Mantids & 0 & $2.00 \pm 0.00$ & 0 \\
\hline Millepeds & 0 & $1.00 \pm 0.00$ & 0 \\
\hline Pseudoscorpions & 0 & 0 & $1.00 \pm 0.00$ \\
\hline Spiders & $6.67 \pm 3.48$ & $7.33 \pm 4.87$ & $9.67 \pm 5.69$ \\
\hline Termites & $13.50 \pm 3.50$ & $65.67 \pm 30.39$ & $45.5 \pm 34.50$ \\
\hline Whiteflies & $1.00 \pm 0.00$ & 0 & 0 \\
\hline
\end{tabular}

Variation in species diversity and abundance of soil macro fauna across land use types

Although the sample size in each land-use type was small (3) quadrats, One-Sample Kolmogorov test showed that both the species diversity and total abundance of soil macro fauna were normally distributed ( $>0.05)$. Therefore, One-way ANOVA, which is a parametric test, was used to test for differences in species diversity and abundance of soil macro fauna across the three land use types. Results indicated that the diversity of macro soil fauna was not significantly different across land use types (ANOVA: $\mathrm{P}=0.544$ ). However, the abundance of soil macro fauna was almost significant across the three land use types (ANOVA: $\mathrm{P}=.097$ ).

Table 3:-Abundances and Shannon diversity of soil macro fauna collected from the different land use types from the different parishes in Namanyonyi Sub County.

\begin{tabular}{|l|l|l|l|l|l|l|l|l|l|}
\hline & \multicolumn{3}{|c|}{ Eucalyptus } & \multicolumn{3}{c|}{ Fallow } & \multicolumn{3}{c|}{ Mixed cropping } \\
\hline Site & $\begin{array}{l}\text { No. of } \\
\text { species }\end{array}$ & $\begin{array}{l}\text { Abun } \\
\text { dance }\end{array}$ & $\begin{array}{l}\text { Shannon } \\
\text { diversity } \\
\left(\mathrm{H}^{\prime}\right)\end{array}$ & $\begin{array}{l}\text { No. of } \\
\text { species }\end{array}$ & $\begin{array}{l}\text { Abund } \\
\text { ance }\end{array}$ & $\begin{array}{l}\text { Shannon } \\
\text { diversity } \\
\left(\mathrm{H}^{\prime}\right)\end{array}$ & $\begin{array}{l}\text { No. of } \\
\text { species }\end{array}$ & $\begin{array}{l}\text { Abund } \\
\text { ance }\end{array}$ & $\begin{array}{l}\text { Shannon } \\
\text { diversity } \\
\left(\mathrm{H}^{\prime}\right)\end{array}$ \\
\hline $\begin{array}{l}\text { Nabwe } \\
\text { ya }\end{array}$ & 6 & 54 & 1.23 & 5 & 206 & 0.82 & 4 & 53 & 0.91 \\
\hline $\begin{array}{l}\text { Namag } \\
\text { umba }\end{array}$ & 6 & 94 & 0.86 & 10 & 241 & 1.04 & 5 & 306 & 0.76 \\
\hline $\begin{array}{l}\text { Nkom } \\
\text { a }\end{array}$ & 6 & 50 & 1.11 & 7 & 281 & 0.96 & 7 & 103 & 1.11 \\
\hline $\begin{array}{l}\text { Mean } \\
+ \text { SD }\end{array}$ & 6 & $\begin{array}{l}66 \\
\pm 14.0 \\
2\end{array}$ & $1.07 \pm 0.11$ & $\begin{array}{l}7.33 \pm 1 . \\
45\end{array}$ & $\begin{array}{l}242.7 \pm \\
21.67\end{array}$ & $0.94 \pm 0.06$ & $\begin{array}{l}5.33 \pm 0 . \\
88\end{array}$ & $154.0 \pm$ & $0.93 \pm 0.10$ \\
77.36 & \\
\hline
\end{tabular}

Relationship Between The Diversity Of Soil Macro Fauna And Physical/ Chemical Properties Of Soil

Distribution of variables was tested using a one-sample Kolmogorov-Smirnov test which showed a normal distribution between soil physicallchemical properties and soil macro fauna diversity, abundance and biomass. Hence, a one-way analysis of variance (ANOVA) was used to test for significance of variables. The results of selected soil properties under different land use types are presented in (table 4). All results were correlated with specific standards provided by the National agricultural research laboratory (NARL) kawanda, Uganda, after analysis. Soil chemical characteristics did not significantly vary across land use types (ANOVA, P>0.05)

Table 4:-Soil properties for the different LUTs in Namanyonyi sub-county

\begin{tabular}{|r|r|r|r|}
\hline Soil Parameter & Eucalyptus & Fallow & Mixed cropping \\
\hline & & & $5.6222 \pm .28371$ \\
\hline $\mathrm{Ph}$ & $5.7556 \pm .12814$ & $5.7667 \pm .17321$ & $3.6097 \pm .13413$ \\
\hline $\mathrm{OM}$ & $2.7804 \pm .34360$ & $3.3301 \pm .62057$ & $1899 \pm 0.00302$ \\
\hline $\mathrm{N}$ & $.1625 \pm 0.01603$ & $.1816 \pm 0.02904$ & $5.7463 \pm 2.35331$ \\
\hline $\mathrm{P}$ & $6.7767 \pm 2.10044$ & $4.5594 \pm 1.33026$ & $1697.4421 \pm 263.83783$ \\
\hline $\mathrm{Ca}$ & $1848.1293 \pm 314.60523$ & $2169.7505 \pm 282.46586$ & $1697.4421 \pm 64.12489$ \\
\hline $\mathrm{Mg}$ & $448.6327 \pm 121.20800$ & $580.7644 \pm 129.81768$ & $141.6023 \pm 43.13560$ \\
\hline $\mathrm{K}$ & $87.0545 \pm 32.26577$ & $131.7399 \pm 31.85108$ & \\
\hline
\end{tabular}

\section{Relationship between soil macro fauna and soil parameters}

A Pearson product moment correlation was used to determine the relationship between soil parameters and species abundance, diversity and biomass. Pearson correlation showed that there is a moderate positive relationship between 
soil macro fauna biomass and calcium $(\mathrm{r}=0.666 . \mathrm{P}<0.05)$, and a negative almost significant relationship between macro fauna diversity and calcium $(\mathrm{r}=-0.68, \mathrm{p}=0.059)$

Variability of earthworms and termites across land-use types One-way ANOVA results showed that there was no significant difference between the biomass of termites across land-use types $(\mathrm{F}=0.842, \mathrm{P}=0.483)$. However, descriptive statistics showed that Termites' biomass varied highly across different LUTs. For example, Fallow LUTs showed the highest biomass $(1.021250 \pm 0.3032234)$, followed by mixed cropping LUTs (0.7500000 \pm 0.75000000$)$, Eucalyptus showed the least with biomass of $(0.616667 \pm 0.3032234)$.

\section{Discussion:-}

Generally, Hymenoptera was the most abundant of the macro fauna groups constituting about (64.77\%) of the total, followed by Isoptera (22.69\%), Aranea (5.12\%), Orthoptera (3.1\%), and Coleoptera (2.83\%) (table1). The other macrofauna groups namely: Chilopoda, Blattidae, Dermaptera, Mantodea, Diplopoda, Hemiptera and Pseudoscorpion, each constituted less $<10 \%$ of the total macrofauna recorded. This agreed with findings of [7], who observed that Hymenoptera and Isoptera were the most abundant of the macro fauna groups constituting about $(56 \%)$ of total macro faunal groups recorded across land use systems of Taita, Kenya. Recent studies in other parts in Kenya have also documented high densities of Hymenoptera and Isoptera [7].

Although differences in the abundance of the individual species were not statistically tested due to small sample size, variations in abundance across land use types were observed to occur (table 2). Ants and termites were the most abundant species of soil macrofauna recorded, and Fallow land use types supported a higher number of individuals of soil macrofauna ( $150 \pm 40.19)$, followed by mixed cropping (105.67 \pm 55.38$)$ and eucalyptus $(43.67 \pm 12.68)$. Spiders had a relatively moderate abundance with mixed cropping supporting the highest $(9.67 \pm 5.69)$, followed by fallow $(7.33 \pm 4.87)$ and eucalyptus (6.67 \pm 3.48$)$. Earwigs, grasshoppers, mantids, millipedes and pseudoscorpions recorded zero (0) abundance in eucalyptus plantations and had a low abundance between $(3.00 \pm 1.00$ and $5.00 \pm 3.33)$ in fallow and mixed cropping land use types respectively. Pseudoscorpions were absent in both eucalyptus and fallow (0) and were only negligibly abundant in mixed cropping (1.00 \pm 0.00$)$. Conversely, whiteflies were only abundant in eucalyptus plantations $(1.00 \pm 0.00)$. This finding contrasts the findings of [7]. Who observed that most macrofauna groups such as Hymenoptera, Oligochaeta, Coleoptera, Diplopoda, Diptera, Arenae, Blattelidae, Hemiptera were found to be more abundant in arable systems but low in the forest ecosystems.

Overall, Eucalyptus plantations were the most diverse of the land use types $\left(\mathrm{H}^{\prime}=1 . \mathrm{O} 7 \pm 0.11\right)$, followed by fallow $\left(H^{\prime}=0.94 \pm 0.06\right)$ and then mixed cropping $\left(H^{\prime}=0.93 \pm 0.10\right)$ were the least diverse (Table 3$)$. This finding also contrasts the observations of [7], who reported that plantation forests was the most diverse of the land use systems, while fallow and mono-cropping were the least diverse land use types in Taita Kenya. However, based on diversity of macro soil fauna in each land use type per parish, Eucalyptus plantations in Nabweya parish had the highest diversity $\left(\mathrm{H}^{\prime}=1.23\right)$, followed by Nkoma $\left(\mathrm{H}^{\prime}=1.11\right)$ and the least diverse was Namagumba $\left(\mathrm{H}^{\prime}=0.86\right)$. On fallow land use types, Namagumba had the highest diversity $\left(\mathrm{H}^{\prime}=1.04\right)$, followed by Nkoma $\left(\mathrm{H}^{\prime}=0.96\right)$ and Nabweya $\left(H^{\prime}=0.82\right)$. Mixed cropping showed the highest diversity of soil macrofauna at Nkoma $\left(H^{\prime}=1.11\right)$, followed by Nabweya $\left(\mathrm{H}^{\prime}=0.91\right)$ and the least was Namagumba $\left(\mathrm{H}^{\prime}=0.76\right)$. Results of this study have shown that fallow LUTs within Namanyonyi sub-county was rich in macrofauna species but had lower species diversity compared to Eucalyptus LUTs which was more diverse with macrofauna groups, mixed cropping was the least diverse LUTs (refer to table 3). However, since the variability of macrofauna groups were sampled and analyzed on the continuum of land use types (eucalyptus, fallow and mixed cropping), it would also be essential to discuss how macro fauna diversity varied across each land use type. Eucalyptus LUTs showed the highest diversity of macro fauna groups in $\left(H^{\prime}=1.07 \pm 0.11\right)$, followed by fallow LUTs $\left(H^{\prime}=0.94 \pm 0.06\right)$ and least diverse were mixed cropping LUTs $\left(H^{\prime}=0.93 \pm 0.10\right)$. Furthermore, from table 3, it could be deduced that overall, fallow supported the highest abundance of soil macrofauna (242.7 \pm 21.67$)$, followed by mixed cropping (154.0 \pm 77.36$)$, and the least abundant LUTs was eucalyptus (66 \pm 14.02$)$. Similar to diversity, abundance varied across land use types in each parish. In eucalyptus plantations, Namagumba recorded the highest abundance (94), followed by Nabweya (54), and Nkoma (50). On fallow land use types, Nkoma parish showed the highest abundance (281), followed by Namagumba (241), and Nabweya (206). on mixed cropping land use types, Macrofauna abundance was highest in Namagumba (306), followed by a relatively moderate abundance at Nkoma (103) and Nabweya (53) (Table 3) 
Soil chemical characteristics did not significantly vary across land use types (ANOVA, P $>0.05$ ). However, descriptive statistics show that the soils are generally acidic, for example, the $\mathrm{pH}$ of soils in eucalyptus land use type was (5.7), fallow (5.76), and that of mixed cropping was (5.07-6.00). Total organic matter content across all the land use types showed medium levels, for example, Mixed cropping recorded the highest with (3.60\%), followed by fallow with (3.3\%) and eucalyptus had the least $(2.7 \%)$.

Total Nitrogen levels across all the land use types depicted medium levels of N. Fallow and mixed cropping land use types recorded equal and medium levels of $0.18 \%$, while Eucalyptus recorded medium levels $0.16 \%$. Total Phosphorus level across all the land use types was deficient. Eucalyptus recorded deficient levels (6.7 ppm), mixed cropping also recorded low levels $(5.7 \mathrm{ppm})$ and fallow recorded the lowest levels $(4.5 \mathrm{ppm})$.

Total Calcium in all LUTs was at high levels. Fallow and Eucalyptus LUTs recorded high levels of calcium (2169ppm and 1848ppm), respectively. Mixed cropping also showed high levels of calcium (1697ppm). Total Magnesium was very high, i.e. levels greater than $145 \mathrm{ppm}$ of the required standard levels provided by NARL. Fallow recorded the highest $(580 \mathrm{ppm})$, followed by mixed cropping $(469 \mathrm{ppm})$ and Eucalyptus was the least (448ppm). Finally, total potassium levels were very high, i.e. levels greater than 69 ppm of the required standard levels provided by NARL. Mixed cropping recorded the highest (141ppm), followed by fallow (141 ppm) and Eucalyptus was the least (87ppm).

However, higher levels of Calcium contributed to a higher biomass of macro fauna groups, and from the analysis, total Calcium in all LUTs was at high levels (table 4). Fallow and mixed LUTs which recorded high biomass also showed high levels of calcium (2169 and1697 ppm) respectively. Eucalyptus also showed high levels of calcium (1848ppm) but negligible biomass in macro fauna groups. However, the diversity of macro fauna groups was negatively affected by Calcium levels, and this may explain why mixed cropping was the least in terms of macro fauna diversity. This is in line with findings of [8], who verified that both mineralogy and levels of exchangeable Calcium have a significant effect on the diversity of soil macro fauna at the order level. In their study, results suggested that the chemical and mineralogical characteristics of soils are important variables explaining the abundance and diversity of macro fauna in Oxisols under pasture use in Cerrado.

Conversely, other soil parameters (Mg, K, O.M, P, PH, and N) did not show any significant relationship with soil macro fauna diversity, abundance and biomass. This finding contrasts the findings of [9] who observed that Soil macro fauna generally have limited abilities to adapt to soil acidity. In tropical soils, invertebrates tolerate lower $\mathrm{pH}$ than in temperate areas, and abundant and active populations may exist in soils with a pH of 3.8 to 4.0.

Furthermore, abundance across the different land use types was positively correlated with biomass. This is not surprising as the highest abundance was recorded in fallow land use types, which also showed the highest biomass of Hymenoptera (ants) and Isoptera (termites). However, diversity negatively correlated insignificantly with biomass, which explains why Eucalyptus with a more diverse macrofauna group, showed the least biomass and in turn the least abundance.

Other soil parameters (O.M, K, Mg, P, N, and PH) showed no significant relationship with soil macrofauna abundance, diversity and biomass across sites. Calcium levels can be assumed as having significant effects on macrofauna abundance and distribution. The significant correlations between soil macro fauna biomass to soil chemical properties indicate that, apart from the direct influence of ecosystem disturbance, cultivation and soil fertility management practices, soil characteristics may indirectly play a role in influencing the density, distribution and structure of macro fauna communities.

Considering that data collection was done during the dry season (December to January), the techniques used in this study were unable to collect earthworms. Most earthworms tend to burrow more in the soil and aestivate. Likewise, A deeper soil depth digging was not adopted in the study to increase the chances of collecting earthworms per monolith. All these reduced chances of collecting earthworms in the study (not even a single earthworm was found during field experiment). Hence the variability of termites biomass was only determined in the study. Furthermore, due to time and material resource constraints, soil bulk densities and porosity were not determined to ascertain how the variability of termites as soil ecosystem engineers may affect soil regulatory functions.

The total number of termites found on fallow LUTs was more extensive than in mixed cropping and eucalyptus land use types (refer to appendix table), although not significantly. 
Other studies on termites have shown that their abundance may increase under mono cropping [10], or that they are not very sensitive to different land use strategies [11]. All species orders found in this study belonged to the family Termitidae.

\section{Methods:-}

\section{Description of the study sites}

Namayonyi is a sub-county in Mbale district Uganda. This sub-county is made up of four different parishes; Nkoma parish which consists of Kanikwa. Bujoroto and Kasanvu; Nabweya parish, Isateko parish and Namagumba parish. During field survey, it was observed that land use types were more evident in 'villages of upper and lower Kasanvu, Bujoroto, Kanikwa and Bude B in Nkoma parish. However, land use types were also identified in the parishes of Nabweya and Namagumba. The land use types practised in Nkoma parish in areas of Kanikwa include eucalyptus and pine tree plantations which are usually cultivated for land demarcation and a few for commercial purposes. Fallow and mixed cropping land use types were prominent in and around Nabweya parish for example at the Kakungulu hill in Nabweya parish, land users in this parish were mainly farmers and landowners mostly put up their lands for sale this explains the reason why some lands were left fallow for a considerable number of years. Datas were collected from four parishes in Namanyonyi Sub County, which is about $2 \mathrm{~km}$ from Mbale town, namely; Nkoma, Nabweya, and Namugumba. (map of the study area can be found in the appendix fig. 1)

\section{Soil physicochemical characteristics}

The soils of Namanyonyi Sub County are largely loamy soils in the last stages of tropical weathering. Their nature renders them fertile for agricultural practices.

\section{Agricultural/economic activity}

Subsistence farming activities are the main economic activities taking place within the sub-county. Most of the agricultural products which are sowed and harvested in this area are either for household consumption or commercial purposes.

\section{Land use types}

Considering that data was collected from the different land use types in the study site, it is essential to explain the different land use types that were identified. The following were the classification of the three land use types that were sampled in Namanyonyi.

\section{Mixed cropping;}

Mixed cropping practised in this sub-county usually involved sowing of annual crops such as maize, beans, cassava and potatoes on the same farmland. However, a few farmlands were identified with the sowing of perennial and annual crops, especially in areas of Nabweya and Namagumba parish. Before sowing, land clearance is carried out usually by tilling (hand hoeing) some days before sowing, followed by harvesting in the subsequent months that followed. Farmlands were left uncultivated for some time before sowing for the second wet season which began from July to October.

\section{Eucalyptus plantations;}

Eucalyptus in this area ranged from mature mono specific plantations with dense canopies to semi-mature plantations with partial mean canopy height and sparse saplings. Litter accumulation and abundance within the plantations were relatively sparse. Eucalyptus plantations range between 4-15 years, and landowners mostly cultivated it for land demarcation and a few for commercial purposes. Eucalyptus plantations were well distributed in all villages under the sub-county and were more concentrated in parishes of Nkoma (Kanikwa, Bude, and Bujoroto) and Namagumba.

\section{Fallow land use types:}

fallow sites in this area have been accompanied by varying intensity of livestock grazing. However, the precise years for fallow is only speculated but not well documented. Therefore, this study was focused on fallow land use types which were thought to have been in practice for the past 3-15 years. 


\section{Sampling design}

At each selected land use type, three sampling points (25x25 cm quadrant) was marked on the ground to indicate the position of the monolith within a transect of $40 \times 5 \mathrm{~m}$. Each plot within the transect was divided into two sampling units which were equally spaced at an interval of 2 meters with the use of a string. Furthermore, nine pitfall traps were installed at roughly 4 meters intervals along one flank of the transect. The pitfall traps were installed in the morning hours and emptied 24 hours later. A total of 3 monoliths and nine pitfall traps were used to collect soil macrofauna for each land use type. Likewise, a termite transect line of $20 \times 2 \mathrm{~m}$ was laid adjacent to the $40 \times 5 \mathrm{~m}$ transect. Within each transect, $10 \times 2$ sections were sequentially sampled, each for a total of 15 minutes per section and the following micro niches were investigated in detail: surface soil and litter down to of about $5 \mathrm{~cm}$; deep accumulation of litter and soil between large buttress roots; epigeal and arboreal termite nests mound.

In the cause of sampling, efforts were made to ensure that all available land use types in various parishes in the subcounty were sampled in each parish to avoid pseudo replication of results during the analysis of data.

A total of 9 plots were sampled in all the three parishes, of these the three land use types (fallow, mixed cropping and eucalyptus) were sampled respectively. The estimated total numbers of monoliths and pitfall traps that were used for data collection in all the three parishes are indicated in the table below;

Table 5:-Showing The Total Number Of Monoliths And Pitfall Traps That Were Used For Collecting Soil Macrofauna Across The Land Use Types In Namanyonyi Sub County

\begin{tabular}{|l|l|l|}
\hline Parish & Number of monoliths & No of pitfall traps \\
\hline Nabweya & 9 & 27 \\
\hline Namagumba & 9 & 27 \\
\hline Nkoma & 9 & 27 \\
\hline Total & 27 & 81 \\
\hline
\end{tabular}

\section{Soil Sampling And Analysis}

In order to characterize the soils in the study area, three, 2-metre deep representative profile soil samples were collected from the walls of the dug monoliths in each of the land use types and the soil samples collected were taken to the National Agricultural Research Laboratory (NARL) at Kawanda, Kampala Uganda, for analysis. Total carbon (C) was determined by Heanes' improved chromic digestion and spectrophotometric procedure; total nitrogen (N) by micro-Kjeldahl digestion followed by distillation. Using the same digestion solution used for $\mathrm{N}$ extraction, phosphorus $(\mathrm{P})$ was measured colourimetrically by a spectrophotometer while potassium $(\mathrm{K})$ was measured by flame photometry. Exchangeable acidity, CEC, exchangeable $\backslash$ calcium $(\mathrm{Ca})$ and magnesium $(\mathrm{Mg})$ were extracted by the Mehlich-3 procedure [12] and then measured using atomic absorption spectrophotometry. The soil $\mathrm{pH}$ was measured in water using a $\mathrm{pH}$ meter in a soil: water ratio of 1:2:5. while organic matter content was measured by Walky-Black potassium dichromate wet oxidation. as described by [13].

\section{Collection and identification of macro soil fauna}

Procedures follow Anderson and Ingram [14] making use of pitfall traps together with the digging of soil monolith of dimensions $25 \times 25 \times 30$ (depth) $\mathrm{cm}$. Three different sampling methods were employed for soil macrofauna collection, and they are described below;

\section{Use of a monolith}

A monolith is a bottomless steel metal box measuring $25 \mathrm{~cm} \times 25 \mathrm{~cm} \times 30 \mathrm{~cm}$. This metal box is used for collecting invertebrates that live below the soil surface. For the purpose of this study, soil macro fauna was collected by excavating three soil monoliths of $25 \mathrm{~cm}$ x25 $\mathrm{cm}$ x $30 \mathrm{~cm}$ per sampling site of the land use type [14]. Each monolith was further divided in 3layers $(0-10 \mathrm{~cm}, 10-20 \mathrm{~cm}$ and $20-30 \mathrm{~cm})$ and hand sorted, removing all the invertebrates $>2 \mathrm{~mm}$ in diameter. A total of 27 monoliths (fallow-9, eucalyptus plantation-9, and mixed cropping-9) were excavated during the period of December 2014/ January 2015.

\section{Transect sampling for termites}

At each sample point a $20 \times 2 \mathrm{~m}$ transect was laid about 8 meters from the monolith. Within each transect, $10 \times 2$ sections were randomly excavated for termites using shovels up to a $5 \mathrm{~cm}$ in depth. In each section the following microhabitats were searched for termites: surface soil to $5 \mathrm{~cm}$ depth; accumulations of litter and humus at the base of 
trees; the inside of branches and twigs; all subterranean nests, mounds, carton sheeting and runways on vegetation, and arboreal nests up to $2 \mathrm{~m}$ above ground level.

\section{Pitfall trap method}

Plastic containers with a depth of $10-15 \mathrm{~cm}$ were used as pitfall traps. The traps were dug in the ground in such a way that the rim of the trap was exactly leveled with the surface of the ground. The traps were fitted at roughly $2 \mathrm{~m}$ intervals along one flank of the transect. The traps were placed during the morning hours and emptied 24 hours later. Each trap contained a little water, to immobilize the insects trapped therein. The macro soil fauna trapped in the pitfall traps, including those obtained from the monolith were counted and preserved in plastic containers containing $4 \%$ formaldehyde before taxonomic characterization.

\section{Statistical analysis}

The statistical analyses were done using IBM SPSS Statistics version 21. One sample Kolmogrov Smirnov test was used to examine whether the diversity and abundance of macro soil fauna were generally distributed across the different land use types. Considering that these data conformed to the normal distribution (P>0.05), a one-way ANOVA was used to determine if the statistical result showed any observed difference in the diversity and abundance of macro fauna across the different land use types. Pearson correlation test was used to determine if there was a relationship between physical and chemical parameters of soil and diversity, abundance and biomass of soil macro fauna.

\section{References:-}

1. Barros, E., Pashanasi, B., Constantino, R. and Lavelle, P., (2002). Effects of land-use system on the soil macrofauna in western Brazilian Amazonia. Biology and Fertility of Soils, 35(5), pp.338-347.

2. Jiménez, J.J., Rossi, J.P. and Lavelle, P., (2001). Spatial distribution of earthworms in acid-soil savannas of the eastern plains of Colombia. Applied Soil Ecology, 17(3), pp.267-278.

3. Lavelle, P., Barros, E., Blanchart, E., Brown, G., Desjardins, T., Mariani, L. and Rossi, J.P., (2001). SOM management in the tropics: Why feeding the soil macrofauna? In Managing Organic Matter in Tropical Soils: Scope and Limitations (pp. 53-61). Springer, Dordrecht.

4. Andersen, A., (2003). Long-term experiments with reduced tillage in spring cereals. II. Effects on pests and beneficial insects. Crop Protection, 22(1), pp.147-152.

5. Okwakol, M.J., (2000). Changes in termite (Isoptera) communities due to the clearance and cultivation of tropical forest in Uganda. African Journal of Ecology, 38(1), pp.1-7

6. Okwakol, M.J.N. and Sekamatte, M.B., (2007). Soil macrofauna research in ecosystems in Uganda. African journal of ecology, 45, pp.2-8.

7. Ayuke, F.O., Karanja, N.K., Muya, E.M., Musombi, B.K., Mungatu, J. and Nyamasyo, G.H.N., (2009). Macrofauna diversity and abundance across different land use systems in Embu, Kenya. Tropical and Subtropical Agroecosystems, 11(2), pp.371-384.

8. Vendrame, P.R.S., Marchão, R.L., Brito, O.R., Guimarães, M.D.F. and Becquer, T., (2009). Relationship between macrofauna, mineralogy and exchangeable calcium and magnesium in Cerrado Oxisols under pasture. Pesquisa Agropecuária Brasileira, 44(8), pp.996-1001.

9. Lavelle, P., Dangerfield, M., Fragoso, C., Eschenbrenner, V., Lopez-Hernandez, D., Pashanasi, B. and Brussaard, L., (1994). The relationship between soil macrofauna and tropical soil fertility. In The biological management of tropical soil fertility (pp. 137-169). Wiley.

10. Zida, Z., Ouédraogo, E., Mando, A. and Stroosnijder, L., (2011). Termite and earthworm abundance and taxonomic richness under long-term conservation soil management in Saria, Burkina Faso, West Africa. Applied Soil Ecology, 51, pp.122-129.

11. Sileshi, G. and Mafongoya, P.L., (2006). Variation in macrofaunal communities under contrasting land use systems in eastern Zambia. Applied Soil Ecology, 33(1), pp.49-60.

12. Mehlich, A., (1984). Mehlich 3 soil test extractant: A modification of Mehlich 2 extractant. Communications in soil science and plant analysis, 15(12), pp.1409-1416.

13. Okalebo, J.R., Gathua, K.W. and Woomer, P.L., (2002). Laboratory methods of soil and plant analysis: a working manual second edition. Sacred Africa, Nairobi, p.21.

14. Anderson, J.M. and Ingram, J.S.I., (1993). A handbook of methods. CAB International, Wallingford, Oxfordshire, 221. 


\section{APPENDICES}

Fig 1:-Showing the Map of the study area.

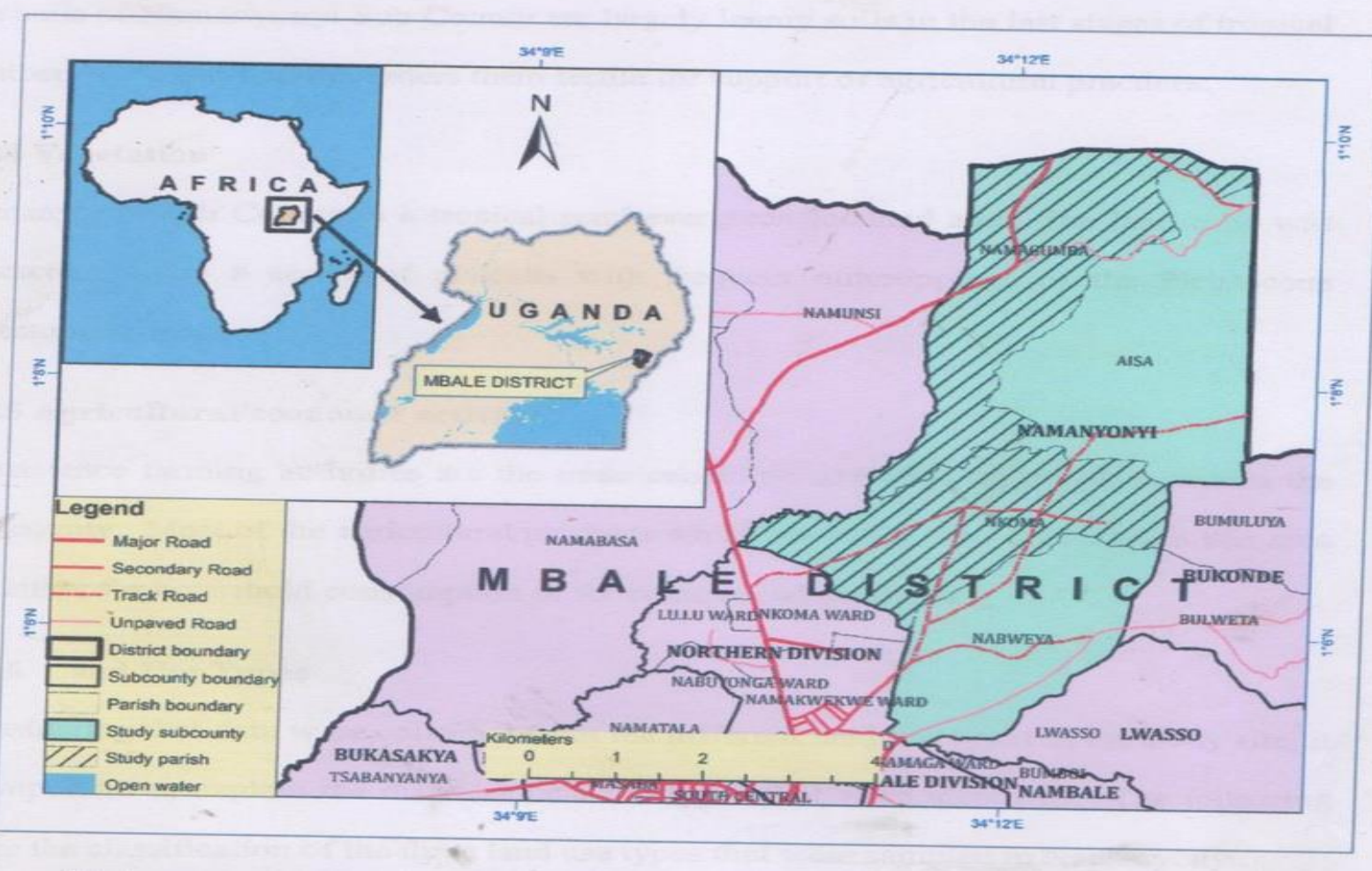

Table 1:-spss anova-output, diversity after the logarithmic transformationiii.

\begin{tabular}{|l|l|l|l|l|l|}
\hline & Sum of Squares & Df & Mean Square & F & Sig. \\
\hline Between Groups & .036 & 2 & .018 & .676 & .544 \\
\hline Within Groups & .162 & 6 & .027 & & \\
\hline Total & .198 & 8 & & & \\
\hline
\end{tabular}

\section{I.}

II.

III. TABLE 2.SPSS ANOVA-OUTPUT, ABUNDANCE AFTER THE LOGARITHMIC TRANSFORMATION

\begin{tabular}{|l|l|l|l|l|l|}
\hline & Sum of Squares & Df & Mean Square & F & Sig. \\
\hline Between Groups & 46816.889 & 2 & 23408.444 & 3.519 & .097 \\
Within Groups & 39906.667 & 6 & 6651.111 & & \\
Total & 86723.556 & 8 & & & \\
\hline
\end{tabular}

Table 3:-SPSS ANOVA-output, soil parameter after the logarithmic transformation

\begin{tabular}{|c|c|c|c|c|c|c|}
\hline \multicolumn{7}{|l|}{ ANOVA } \\
\hline & & Sum of Squares & Df & Mean Square & $\mathrm{F}$ & Sig. \\
\hline \multirow[t]{3}{*}{ pH_mean } & Between Groups & .039 & 2 & .019 & .153 & .862 \\
\hline & Within Groups & .761 & 6 & .127 & & \\
\hline & Total & .800 & 8 & & & \\
\hline \multirow[t]{3}{*}{ OM_mean } & Between Groups & 1.068 & 2 & .534 & 1.025 & .414 \\
\hline & Within Groups & 3.127 & 6 & .521 & & \\
\hline & Total & 4.195 & 8 & & & \\
\hline N_mean & Between Groups & .001 & 2 & .001 & .534 & .612 \\
\hline
\end{tabular}




\begin{tabular}{|c|c|c|c|c|c|c|}
\hline & Within Groups & .007 & 6 & .001 & & \\
\hline & Total & .008 & 8 & & & \\
\hline \multirow[t]{3}{*}{ P_mean } & Between Groups & 7.387 & 2 & 3.693 & .315 & .741 \\
\hline & Within Groups & 70.317 & 6 & 11.719 & & \\
\hline & Total & 77.704 & 8 & & & \\
\hline \multirow[t]{3}{*}{ Ca_mean } & Between Groups & 349222.153 & 2 & 174611.076 & .703 & .532 \\
\hline & Within Groups & 1490242.896 & 6 & 248373.816 & & \\
\hline & Total & 1839465.049 & 8 & & & \\
\hline \multirow[t]{3}{*}{ Mg_mean } & Between Groups & 62219.425 & 2 & 31109.712 & .872 & .465 \\
\hline & Within Groups & 213936.074 & 6 & 35656.012 & & \\
\hline & Total & 276155.499 & 8 & & & \\
\hline \multirow[t]{3}{*}{ K_mean } & Between Groups & 5069.512 & 2 & 2534.756 & .647 & .557 \\
\hline & Within Groups & 23497.505 & 6 & 3916.251 & & \\
\hline & Total & 28567.017 & 8 & & & \\
\hline \multirow[t]{3}{*}{ biomass_mean } & Between Groups & .563 & 2 & .282 & 11.190 & .009 \\
\hline & Within Groups & .151 & 6 & .025 & & \\
\hline & Total & .714 & 8 & & & \\
\hline
\end{tabular}

Table 4:-Tukey HSD showing the difference in soil parameters across the different land use types

\begin{tabular}{|c|c|c|c|c|c|c|c|c|c|c|}
\hline \multicolumn{11}{|l|}{ Descriptive } \\
\hline & & \multirow[t]{2}{*}{$\mathrm{N}$} & \multirow[t]{2}{*}{ Mean } & \multirow[t]{2}{*}{$\begin{array}{l}\text { Std. } \\
\text { Deviation }\end{array}$} & \multirow[t]{2}{*}{ Std. Error } & \multicolumn{3}{|c|}{$\begin{array}{l}95 \% \text { Confidence Interval for } \\
\text { Mean }\end{array}$} & \multirow[t]{2}{*}{ Minimum } & \multirow[t]{2}{*}{ Maximum } \\
\hline & & & & & & Lower Bound & \multicolumn{2}{|c|}{ Upper Bound } & & \\
\hline \multirow[t]{4}{*}{ pH_mean } & 1 & 3 & 5.7556 & .22194 & .12814 & 5.2042 & 6.3069 & & 5.57 & 6.00 \\
\hline & 2 & \multicolumn{2}{|r|}{5.7667} & .30000 & .17321 & 5.0214 & \multicolumn{2}{|l|}{6.5119} & 5.47 & 6.07 \\
\hline & 3 & 3 & 5.6222 & .49141 & .28371 & 4.4015 & \multicolumn{2}{|l|}{6.8429} & 5.07 & 6.00 \\
\hline & Total & 9 & 5.7148 & .31628 & .10543 & 5.4717 & \multicolumn{2}{|l|}{5.9579} & 5.07 & 6.07 \\
\hline OM_mean & 1 & 3 & 2.7804 & .59512 & .34360 & 1.3020 & 4.2588 & & 2.09 & 3.16 \\
\hline & 2 & 3 & 3.3301 & 1.07486 & .62057 & .6600 & 6.0002 & & 2.44 & 4.53 \\
\hline & 3 & 3 & 3.6097 & .23233 & .13413 & 3.0326 & 4.1869 & & 3.42 & 3.87 \\
\hline & Total & 9 & 3.2401 & .72415 & .24138 & 2.6835 & 3.7967 & & 2.09 & 4.53 \\
\hline N_mean & 1 & 3 & .1625 & .02777 & .01603 & .0935 & .2315 & & .13 & .18 \\
\hline & 2 & 3 & .1816 & .05030 & .02904 & .0567 & .3066 & & .14 & .24 \\
\hline & 3 & 3 & .1899 & .00524 & .00302 & .1769 & .2029 & & .19 & .20 \\
\hline & Total & 9 & .1780 & .03131 & .01044 & .1539 & .2021 & & .13 & .24 \\
\hline P_mean & 1 & 3 & 6.7767 & 3.63807 & 2.10044 & -2.2608 & 15.8141 & & 2.58 & 9.03 \\
\hline & 2 & 3 & 4.5594 & 2.30407 & 1.33026 & -1.1642 & 10.2830 & & 1.90 & 5.97 \\
\hline & 3 & 3 & 5.7463 & 4.07605 & 2.35331 & -4.3792 & 15.8717 & & 1.56 & 9.70 \\
\hline & Total & 9 & 5.6941 & 3.11656 & 1.03885 & 3.2985 & 8.0897 & & 1.56 & 9.70 \\
\hline Ca_mean & 1 & 3 & 1848.1293 & 544.91225 & 314.60523 & 494.4922 & 3201.766 & & 1452.08 & 2469.58 \\
\hline & 2 & 3 & 2169.7505 & 489.24523 & 282.46586 & 954.3980 & 3385.103 & & 1605.18 & 2469.58 \\
\hline & 3 & 3 & 1697.4421 & 456.98052 & 263.83783 & 562.2395 & 2832.644 & & 1305.37 & 2199.32 \\
\hline & Total & 9 & 1905.1073 & 479.51343 & 159.83781 & 1536.5206 & 2273.694 & & 1305.37 & 2469.58 \\
\hline Mg_mean & 1 & 3 & 448.6327 & 209.93842 & 121.20800 & -72.8833 & 970.1486 & & 207.19 & 588.16 \\
\hline & 2 & 3 & 580.7644 & 224.85083 & 129.81768 & 22.2040 & 1139.324 & & 335.95 & 778.05 \\
\hline & 3 & 3 & 380.4763 & 111.06757 & 64.12489 & 104.5692 & 656.3835 & & 316.35 & 508.73 \\
\hline & Total & 9 & 469.9578 & 185.79407 & 61.93136 & 327.1438 & 612.7718 & & 207.19 & 778.05 \\
\hline K_mean & 1 & 3 & 87.0545 & 55.88596 & 32.26577 & -51.7739 & 225.8829 & & 30.39 & 142.13 \\
\hline & 2 & 3 & 131.7399 & 55.16766 & 31.85106 & -5.3042 & 268.7839 & & 68.50 & 169.99 \\
\hline & 3 & 3 & 141.6023 & 74.71306 & 43.13560 & -43.9952 & 327.1999 & & 62.33 & 210.72 \\
\hline & Total & 9 & 120.1322 & 59.75682 & 19.91894 & 74.1991 & 166.0654 & & 30.39 & 210.72 \\
\hline biomass_mean & 1 & 3 & .2828 & .25352 & .14637 & -.3470 & .9125 & & .12 & .58 \\
\hline & 2 & 3 & .7957 & .07070 & .04082 & .6201 & .9713 & & .72 & .86 \\
\hline & 3 & 3 & .2490 & .07889 & .04554 & .0530 & .4450 & & .18 & .33 \\
\hline & Total & 9 & .4425 & .29877 & .09959 & .2128 & .6722 & & .12 & .86 \\
\hline & & & & & & & & & $\begin{array}{r}1=\text { eucaly } \\
2=\text { fa } \\
\text { Mixed crop }\end{array}$ & \\
\hline & & & $\begin{array}{c}\text { ut, termites bioma } \\
\text { Sum of Squares }\end{array}$ & $\frac{\log i}{\mathrm{Df}}$ & & $\begin{array}{l}\text { rmation } \\
\text { Mean Square }\end{array}$ & & $\mathrm{F}$ & & \\
\hline Between Group & & & 1.666 & 2 & & .833 & & .846 & & \\
\hline Within Groups & & & 4.925 & 5 & & .985 & & & & \\
\hline Total & & & 6.591 & 7 & & & & & & \\
\hline
\end{tabular}


Table 6:-showing the required standards given by NARL, Kawanda on the physico/ chemical properties of soil across the different land use types in Namanyonyi sub county.

\begin{tabular}{|c|c|c|c|c|c|c|}
\hline \multicolumn{5}{|c|}{ Classification of mehlich 3 extractable nutrients } & \multicolumn{2}{|c|}{ Rating for total $\mathrm{N}$ and Organic matter } \\
\hline & $\mathbf{P}$ & $\mathbf{K}$ & $\mathbf{C a}$ & Mg & $\mathbf{O M}$ & $\mathbf{N}$ \\
\hline & & & & & 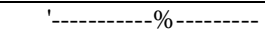 & \\
\hline Very low & $0-12$ & $0-20$ & $<330$ & $<17$ & $0.7-1.0$ & $<0.05$ \\
\hline Low & $12.5-22.5$ & $20.5-40.5$ & $330-655$ & $17-46$ & $1.0-1.7$ & $0.05-0.15$ \\
\hline Medium & $23-35.5$ & $41-72.5$ & $655-1640$ & $46-87$ & $1.7-3.0$ & $0.15-0.25$ \\
\hline High & $36-68.5$ & $73-138.5$ & $1640-3280$ & $87-145$ & $3.0-5.15$ & $0.25-0.5$ \\
\hline Very high & $>69$ & $>139$ & $>3280$ & $>145$ & $>5.15$ & $>0.5$ \\
\hline
\end{tabular}

